\title{
\begin{tabular}{l|l} 
NSULARITY AND THE POLITICAL ECONOMY \\
OF TOURISM \\
An Anthropological Analysis of Zlarin Island
\end{tabular} and the Trenta Valley
}

\author{
Peter Simonič \\ Department of Ethnology and Cultural Anthropology, \\ Faculty of Arts, University of Ljubljana
}

This paper combines environmental, communitarian and political-economic forces to explain cultural heritage and tourism on Zlarin Island (Croatia, Dalmatia) and in the Trenta Valley (Slovenia, Alps). The two selected places belong to different geo-cultural areas and academic traditions, but also share many common features including late colonisation, intensive agriculture and overpopulation, population decline in the twentieth century, change in ownership structure, early origins of tourism and use of their insularity as an advantage in their tourism strategies. A comparative analysis offers a chance to rethink the ethnological approach to communities and cultures as insulated entities.

Keywords: Adriatic, Alps, agriculture, environment, demography, industrialisation, stress, cultural heritage, Zlarin, Trenta

When I was searching for a suitable island to start my long-intended research in Dalmatia, my colleague Bojan Baskar suggested Zlarin. Intensive work by Croatian colleagues from 1979 to 1982 (Narodna umjetnost 17/1980; Narodna umjetnost 18/1981; Bezić et al. 1982) motivated my colleague's proposition. It was possible to find additional material on the island in some older, related publications (e.g., Fortis 1778; Perić 1934; Korenčić 1979). Another significant contribution came from a local writer (Dean 2004), with publishing support from the Institute for Migration and Ethnic Studies in Zagreb (see Lajić, Podgorelec and Babić 2001). In autumn 2011, the week-long "Practical Training in Ethnology of Europe" took place on Zlarin. The topics of my first ethnographic survey with around forty students were fishing, agriculture, ethnobotany and anthrozoology, youth, migrations, and cultural heritage. In 2015, another group of students collected individual biographies and information on various communitarian institutions on the island, including households, villages, fraternities, commons, cooperatives, tourism societies, festivities, etc. (see Sahlins 1972; Cohen 1985; Douglas 1986; Ostrom 1990). ${ }^{1}$

${ }^{1}$ All authors deal with communities in various ways: Sahlins through reciprocity (distribution), Cohen through symbols, Douglas through institutions and Ostrom through management of commons. Ostrom used Robert 
Material from and about Trenta was collected from 2011 to 2014 as part of a joint research project between the Slovenian Academy of Sciences and Arts in Ljubljana (Institute of Slovenian Ethnology), and the University of Ljubljana, Faculty of Arts (Department of Ethnology and Cultural Anthropology). Research reports on problems and solutions regarding the communities in Triglav National Park (TNP) were published several times (see Fikfak, Bajuk Senčar and Podjed 2014; Simonič 2014a). Apart from this, considerable interest in the Alps started in the second half of the nineteenth century, when many curious people with different national backgrounds visited Trenta (see Karl C. Czernhausen, Das Land Görz und Gradisca: mit Einschluss von Aquileja, 1873; Morelli di Schönfeld, Istoria della Contea di Gorizia, 1855-56; Simon Rutar, Zgodovina Tolminskega, 1882, etc.). In 1907, Chaplain Jože Abram published a detailed feuilleton called Opis Trente (Description of Trenta). Another series of studies in Trenta were done in the 1980s (see Wraber 1980; Kunaver 1988) and again a decade before my work in the valley (see Komac 2003; Vranješ 2006).

The ethnographic studies combined in this article had different scientific starting points. There was no plan or comparative intention to start with. However, as I occasionally worked in both places, some interesting parallels and distinctions started to appear regarding their late colonisation, ethnological and historical discoveries, geographical limitations, demography and human relations, development strategies etc. $^{2}$

Even though these localities were originally selected independently with different goals and collaborators, they have followed a similar methodology: short, prepared and guided team research carried out by students, consisting of observations and interviews (around sixty in Trenta and sixty on Zlarin), transcriptions and analyses of them, and individual research concerning seasonal variations, socio-economic histories of the region, holidays, etc. The individual histories of interlocutors and information on different past and present local communitarian institutions (from household to empire) were two complementary methods of data collection. ${ }^{3}$

The comparative interpretation presented in this article also has a common pattern. To make common sense of both cases, I decided to follow the examples of David Gilmore (1982) and Pier Paolo Viazzo (2014 [1989]), recognized specialists in these two "culture areas" - Alpine and Mediterranean. Gilmore listed several approaches present in anthropological writings on the Mediterranean: geo-ecological, cultural, historical and political economy. I found value in Gilmore's taxonomy for assessing both Zlarin and Trenta. Viazzo, on the other hand, analysed anthropological writings on the Alps, and suggested a combination of ecological, demographic/

Netting's study of a pastoralist (Balancing on an Alp, 1981) to defend a third way in economy, but never mentioned anthropology in her Nobel prize winning book.

${ }^{2}$ A first draft of this article was prepared for $12^{\text {th }}$ Croatian-Slovenian Ethnological Parallels: "Redrawing the Borders. Transformations of Identities and Redefinition of Culture Regions in the New Political Circumstances" (Duga Resa, Croatia, 23-25 September 2012).

${ }^{3}$ Materials collected in both projects are available at the Documentation Office at the Department of Ethnology and Cultural Anthropology, Faculty of Arts, University of Ljubljana (Simonič 2014b, 2017). 
kinship and historical points of analysis. I have combined and summarised these approaches into three sections. Later, I will use the material collected to describe some social mechanisms and meanings of tourism in these communities.

I do not wish to convince readers that there is some kind of ideal overlap between these locales, but that comparative analysis enables us to see much wider connections between scientific, social, cultural and environmental issues, and their combined influence on the shape of contemporary local tourism. Certainly, by focusing just on a specific set of data, I will not be able to address many other possible perspectives, contents and references, and I will also be unable to present every aspect in depth and ethnographic illustration.

In both cases, I will consider only modern European history ("structural timespace” of post sixteenth century World Systems; Wallerstein 1998) and mostly set aside Illyrian, Roman and Slavic colonisations of the Alps and Dalmatia ("eternal time-space", e.g., myth of ethnic origins; ibid.).

\section{Geo-environmental approach}

Both locations are partially Alpine and partially Adriatic. Alpine and Pannonian cultural and political circles have strongly influenced Dalmatia throughout history (Noé 1870; Lendvai 2003; etc.). The Trenta Valley lies in the Julian Alps, which are distinguished by the influence of an Adriatic climate, culture and politics undoubtedly to a greater extent than are most other parts of the Alps.

What attracted me to Zlarin and Trenta in the first place was their geographical insularity and how it defines my perception. In both localities, Carneiro's theory of environmental circumscription (1970) seemed an appropriate point to start. A natural separation from other communities and the mainland (urban centres) defines both Zlarin Island and the Trenta Valley. Local communities and their scientific interpretations are geographically "trapped" inside sharply defined natural limits, and are also faced with a scarce amount of soil (and water) for agriculture. This is true for many valleys and islands.

Zlarin measures eight square kilometres. Low hills form a shallow basin of arable land in the middle of the island. Trenta extends about 20-30 kilometres from southwest to northeast, and covers about the same number of square kilometres (long and narrow, woody, with many mountain pastures, foothills and slopes). It was impossible for both "islands" to expand and develop any large-scale political hierarchies. Environmentally circumscribed communities in the agricultural areas of several square kilometres remained low in population and stratification.

Arable land was hard to find both on Zlarin and in Trenta: the soil is shallow, and in the Alps the terrain might also be too steep. Stone created problems in the fields, but as a construction material it was available in abundance (inexpensive), and was stable and long-lasting. Many old buildings on Zlarin are still in good condition to- 
day because stone was the dominant construction material. In Trenta, where they also used timber, architectural heritage vanishes faster, or only ground floors made of stone have been preserved.

The social life of the preindustrial inhabitants was organised according to seasons, as in other Alpine valleys and on the Adriatic islands, and in fact in most preindustrial societies. Winters are of course milder on Zlarin, but could also be very unpleasant for any outdoor activities. The most fruitful season on Zlarin is late spring to early fall, and the harvest traditionally includes garden vegetables, grain, fish and grapes. On Zlarin, November has been recorded as the month for the olive harvest for at least six hundred years (Stulli 1980). Traditional agriculture in Trenta was also concentrated in the period from May to September, with forestry, transhumance, gardening, fairs, rituals, etc.

Zlarin and Trenta are certainly not identical in their insularity. The sea presents immediate limits to island communities, but it also offers openness and horizons. Mountains, on the other hand, represent a definite end, with the steep closeness of Alpine valleys. From a local point of view, Alpine adventures do not offer the same open contact to all continents (World), as the sea promises.

Transport of goods and people deserves special attention for insulated people: the boat Tivat, which has connected Zlarin to the coastal town of Šibenik since 1972, is an object of gratitude (and a lyrical documentary of its glory is currently in production). The road to Bovec (1901; see Abram 1907) and especially the road through Vršič (1915-16), are cherished in Trenta's consciousness. After 1916, the valley was no longer an almost unapproachable "dead end" of the Julian Alps, and it became one of many useful passes through the Alps (connecting Bovec and Kranjska Gora). Both infrastructures (boat and road) were essential not just for locals, but also for tourists.

Trenta has never had any serious problems with water; there is plenty in the Alps. On Zlarin, water insufficiency was a serious and common threat, and everything depended on gusterne (rainwater collectors and tanks). In 1978, a continental water pipeline erased this ancient stress (see Moran 2000: 7) and opened the door for further development of life and tourism on the island. Today, water pipelines, phone, electricity, internet, etc. are standard in both locations.

Cultural insulation is most likely to be associated with valleys and islands, while insulation in the sense of invention (discovery), separation, protection and sacrifice of concepts, myths, identities, territories or societies is quite present in all European (sedentary) philosophy, literature and politics (Shell 2014). In tune with this, Alexander Lopašić wrote:

We can perhaps conceptualize Mediterranean islands as areas, where Mediterranean identity has survived best because of the islander's ability to preserve their own traditional social structure through isolation and separation from the mainland (...) in this way the islands became symbols of and refuges for the traditional way of life. (Lopašić 2001: 366-369) 
In this quotation, communities' geographic insulation is almost equivalent to low social dynamics and cultural change. In 1981, cultural ecologist Robert Netting introduced the Alpine village Törbel (Switzerland) as "an island in the sky" (see reflections in Netting 2007: 309). ${ }^{4}$ During the last few decades, ethnographic and theoretical frameworks of peasant, island and highland communities have been globalised and contextualised in every aspect (see Leach 1970 [1954]; Wolf 1973 [1969]; Davis 1977; Gilmore 1982; Muraj 1981; Wolf 1998-1999; Appadurai 2003 [1996]; Vranješ 2006; Prica and Jelavić 2009; Viazzo 2014, etc.). Yet, the perception of Alpine and Adriatic communities as distinct and authentic remains important for tourism, in which local natural and cultural heritage is transformed into economic capital (commodity) as a point of competition among destinations (Lowenthal 1998; Kozorog 2013). The geographical insularity of valleys and islands is charming and beneficial. Insularity can be associated with pristine life and wilderness on the margins of municipalities and states. Trenta and Zlarin's geo-cultural detachment and (industrial) underdevelopment became an important feature of their social histories and (eco)tourism strategies.

Tourism is certainly not the first kind of political economy, reasoning and practice in both localities. They have been (re)discovered and (re)shaped several times. From the Middle Ages, the communities of Trenta and Zlarin have found themselves on the borders of Roman, German, Slavic and Ottoman Europe (Stulli 1980; Peričić 1980; Wolff 1997; Lajić, Podgorelec and Babić 2001; Panjek 2002; Strathern 2013; Baskar 2010).

\section{History, political economy and demography}

From the fourteenth to the sixteenth centuries, the central valley of Bovec (today a municipality that includes Trenta) was already overpopulated, which triggered expansion into the upper valleys and forests. Exploitation of timber and iron encouraged further advances into the mountains (Mlekuž 2002). Significant and rapid settlement of Zlarin was also recorded in the sixteenth century, when peasants and pastoralists from the extended Šibenik hinterlands (Zagora) searched for a safe place from the expanding Ottoman Empire. The colonisation of both places occurred rather late. It became necessary and involved large numbers of people at a specific point in time. Trenta and Zlarin should be seen as late choices for communities based on agriculture, while both localities were originally suitable for pasturing. On Zlarin, pasturing eventually became marginal due to vineyards, but locals owned and maintained such properties on both the mainland and on islands like Zablaće, Drvenik, Rakitnjak, Dvainka, Mumonja, Seka, Vrtljaća, etc. (Stulli 1980: 17). In Trenta, which was even more inappropriate for intensive agrarian cultivation,

\footnotetext{
${ }^{4}$ Compare Lopašić's and Netting's stance to traditional anthropological interest in small and (conceptually) insulated ethnic groups ("cultures"), like Malinowsky on Trobriands (1984 [1922]); Fortes and Evans-Pritchard on Tallensi and Nuer (1950 [1940]), Steward on Shoshone (1955), etc.
} 
pasturing remained an important part of semi-nomadic subsistence and diary production until the middle of the twentieth century (Mlekuž 2002). In short, Zlarin transformed many pastoralists escaping from the continent into agriculturalists on the island, while Trenta underwent an expansion of pasturing and a transformation of forests into fields and thus commodities. Their new lands were not beyond the reach of the regional political economy, but were already in the possession of municipalities, the Church and other aristocrats.

Agricultural life both in Trenta and on Zlarin was demanding. In both cases, traditional households depended on minifundiums (small holdings). Older female interviewee described gardening around or near the house as a basis for the local cuisine. Sheep and wool were essential in both places for clothes, blankets, and in Trenta for trade as well. Goats were another very important source of nutrition for many families in Trenta in the middle of the nineteenth century (Komac 2003: 145146). Up to the nineteenth century, fishing and hunting were additional sources of food (and income) in Trenta and on Zlarin.

All of this was not sufficient to sustain and justify colonisation. Another branch of activities in both sites was market orientated and controlled by property owners. Zlarin was part of the Venetian Republic (officially 1409-1897, but in actuality from the eleventh century), which legally supported an agricultural colonate system and developed an appropriate organisation for agricultural lands: vineyards to olive trees ratio, taxes, etc. (Stulli 1980; Muraj 1981; Blažević 2007). Living and working conditions were harsh, and hunger was common (Defilippis 2013: 291-292). Wolff cited several sources by which seventeenth century Dalmatia was in "miserable poverty, aggravated by recurrent famines and plagues, and its social tensions corresponding to an inequitable concentration of agricultural land" (Wolff 1997: 429). Dalmatia also served Venice as a "Catholic bulwark" against Turkish expansion: the ratio there of eleven priests for every one thousand believers was the highest rate in Europe (Peričić 1980: 55).

Coral fishing had been quite profitable, but for a long time mostly for Neapolitan traders and Venice, but not for islanders. Alberto Fortis noticed in the second half of the eighteenth century that:

$[\mathrm{I}]$ slanders, though frequently employed in the coral boats, have not yet been able to learn the wonderful art of extracting the coral from narrow and deep caverns under water (...). And it is the more to be wondered (...), that the art of fishing is not well understood by the Dalmatians, considering how ancient the trade of it is at Sibenico. (Fortis 1778: 154)

Around fifty years later, during the Austrian period, coral fishing appeared as an important legacy and art of the islanders (Perić 1939). Coral became one of the most precious features of Zlarin's cultural and natural heritage.

Bovec and its surroundings looked poor to fifteenth century Italian traveller Paolo Santonino (Komac 2003: 20). In 1520, a peace treaty between the Venetians and the Hapsburgs gave Trenta to the later (Panjek 2002; Komac 2003: 21). During 
sixteenth and seventeenth centuries, the iron industry emerged in the Alps (Cole 1972). In the upper Trenta valley, workers from Trentino (another Alpine centre) established a new industrial colony, which operated for two hundred years and stimulated the development of the village of Trenta and the entire valley (Wraber 1980; Mlekuž 2002). Timber was always a premium export good. Finally, at the end of the nineteenth century after two local boys were sent to visit the Swiss Alps, cheese products became an export good ("niche") for many transhumant pastoralists from Trenta (Komac 2003: 146). Forestry, gardening and pasturing enabled a population increase during the nineteenth century (Rutar 1889). In 1869, 357 houses in the valley possessed around ten thousand sheep and goats. Families had up to six children, but less than half of them reached the age of twenty (Komac 2003: 41).

In 1797, Zlarin was also included in Hapsburg Empire. Even when these two places belonged to different states, they basically depended on Venetian market: the Hapsburgs sold timber and iron from Trenta to their neighbour (Mlekuž 2002), and control over wine and oil from the Dalmatian islands was a matter of tribute and loyalty to Venice (Wolff 1997; Stulli 1980).

Zlarin became a kind of transportation hub for the surrounding district of the Habsburg Monarchy (Kingdom of Dalmatia) in 1826. The second Austrian administration in Dalmatia invested largely in basic state functions, and Zlarin's deep bay became a transfer harbour for the surrounding islands. It was a municipality with a school, a post office, a customs house, and a resident doctor (Muraj 1981: 276). This administrative position gave Zlarin special meaning in the inter-island community, whose inhabitants were known in the local dialect as boduli. Similar to Trenta, Zlarin experienced its height of population (3,036 inhabitants) in the middle of the nineteenth century (Korenčić 1979: 673). The results were obvious: in the seventeenth century, the ratio between cultivated and uncultivated land on the island was 50:50, while in the nineteenth century this ratio was a staggering 90:10 (Stulli 1980: 53, 75).

Intensive agriculture in vineyards mixed with olives plantations on Zlarin, and forestry, pasturing (and iron making) in Trenta, changed (domesticated) the landscapes to meet personal needs and expectations of landowners (and foreign markets). The nineteenth century was critical in a demographic, political, social and ecological sense in both geographically insulated communities (comp. Blažević 2007; Mlekuž 2002).

The London Agreement (1915) and Treaty of Rapallo (1920) ceded Trenta and Zlarin to Italy. On Zlarin, Italian rule only lasted until 1921 (and again in 19411943; Stulli 1980: 35, 39); while during World War I the people of Trenta witnessed a complete devastation of the valley (Soča front) and the rule of fascism (since 1923; Dolenc 1988); Italians asphalted the road from Bovec to Trenta village as part of a modernisation process in the rural Alps.

On Zlarin and in Trenta, peasant-owned smallholdings were not established until the nineteenth century after the emancipation in Habsburg Empire (1848; Defilippis 2013), and again during the Yugoslav land reform before and after World War II (Blažević 2007: 645; Čepič 1995). In the nineteenth century, peasants on 
Zlarin bought up land, but many soon fell into debt, sold the land, or left the island in order to repay their debts and support their families (delegated emigration; Lajić, Podgorelec and Babić 2001). In Trenta, the dominant local transhumance was based on common feudal servitude and property rights in the mountains (Vilfan 1996: $352)$.

The Ottoman, Hapsburg-Austrian, Venetian-Italian, and Yugoslav states and markets were decisive actors in economic integration, material prosperity, growing populations and the increasing number of institutions on Zlarin and in Trenta. Major contextual breaks and corresponding social collapses on Zlarin and in Trenta similarly appeared after state interventions. Historical literature concerning Zlarin could not avoid the wine crisis: after Austria-Hungary and Italy signed a trade agreement known as the Wine Clause (1892), by which Austrian (and German) traders were encouraged to buy Italian wines instead of those produced locally. The prices of Dalmatian wines fell (Edinost 1892; Lajić, Podgorelec and Babić 2001: 34), and then in 1894 downy mildew finally destroyed the island's viticulture. Interestingly, Korenčić's historical-demographic tables (1979) do not show any drop in the number of inhabitants on Zlarin immediately after the economic and biological wine crisis. Perhaps this was due to the birth rate compensating for economic migration. Or perhaps people were still registered as living on Zlarin, when they in fact lived in Šibenik, Split, Zagreb, Germany or the USA. ${ }^{5}$ It was not until the 1920s that statistical records demonstrated a notable population decline on Zlarin. The coral harvest, which had once been profitable, was abandoned in the 1950s along with the cooperative due to new, large discoveries near Sicily. Steamships made local production of sailboats obsolete before World War I (Stulli 1980; Lajić, Podgorelec and Babić 2001), etc. By the middle of the twentieth century, the old agricultural foundation of Zlarin was gone.

Trenta managed though public protests to block state restrictions on sheep and goats in the middle of the nineteenth century (Komac 2003: 145). Almost a hundred years later, the Yugoslav Law on Forests (1953) strictly prohibited goat pasture in all woodlands. Resistance from the locals was weak. In local opinion today, the prohibition was a breaking point for "traditional culture" and the beginning of the valley's depopulation. The state immediately offered assistance through a reinvention of the valley. In the same year, the Trenta Museum (Trentarski muzej) was opened and an ethnographic and environmental case was slowly built for the creation of the Triglav National Park in this area (1981).

Other reasons for the rapid deagrarianisation and depopulation of Zlarin and Trenta in the twentieth century were industrialisation and urbanisation - both attractive factors driving migration. Trenta historically gravitated towards Bovec and towards Tolmin and Gorica, but also further south towards Trieste or the woods and factories in the German north. Starting in the 1950s, people from around Šibenik, including those from nearby islands, were invited to work in factories in Split, Zadar,

\footnotetext{
${ }^{5}$ Similar statistical distortion is present today, mostly for tax avoidance: out of 280 registered inhabitants, only about 120-150 live on the island. I did not check these ratios in Trenta.
} 
Zagreb, Germany, etc. Many people from Zlarin left permanently, or they might have still visited or rented a renovated parents' house.

In short, emigration and immigration in two geographically insulated, agrarian communities occurred due to military conflicts, new means of transportation, the development and dissolution of mining/industry, illness, overpopulation and depopulation, and the collapse of various social systems (see Babić, Lajić and Podgorelec 2004).

It would thus appear that these communities were never truly isolated - neither according to their origin (expansion, refugees), nor according to their work and belonging (religion, colonists, taxes, roads). They have been "balancing" between their original socio-cultural systems, environmental limitations, landowners and traders.

\section{Culture and local communitarianisms}

Today, the average age of the approximately two hundred residents in Trenta and two hundred on Zlarin is around sixty-five years. In the twentieth century, young men gradually left in search of work, and often established their families elsewhere. For both locations, the twentieth century was a time of population decline and feelings of social despair.

The cultures of these communities include various symbolisms, commemorations, languages etc., while the socio-economic aspect of the communities is accessible through a variety of cooperative institutions intended to secure material reproduction. Regarding symbols, Marks (1980), Bezić (1981), and Rajković (1981) have offered detailed insight into Zlarin's cultural heritage. The agricultural mass mode of production, its material aspects, songs and dances etc. are at the centre of this inheritance, and are more desirable in comparison to fishing and herding. Only coral can compete with traditional agriculture in today's presentation of the island's heritage. An ethnographic exhibition and a folk dance troupe on Zlarin have captured some aspects of a vanished social model. A folklorised version of Trenta's economy and other aspects of its traditional life can be seen in the programming of contemporary local cultural and tourism societies, but the most important one is at a large museum at the TNP Info Centre (see e.g., Wraber 1980), located in Trenta at one of the entrances to Triglav National Park since 1996. Visitors can learn about the valley's geological, economic, political, biological, zoological and tourism history. Both places of ethnographic presentation and reflection also serve as meeting points for various artists, researchers, delegations etc.

According to field notes and historical records, Zlarin and Trenta were patrilocal, but the differing character and intensity of emigrations had different influences on gender relations. Work in Italian, Austrian, German, Bosnian, and even American mines and forests was common for Trenta's men until World War II, but the majority of them returned seasonally. In Trenta, the oldest son inherited the household pos- 
sessions in the pastoralist community. He thereby became a member of an exclusive group - the village transhumance fraternity - and later the agrarian community. In both places, marriage arrangements between families show a regular pattern of the bride symbolically and literally moving to her groom's house. If her husband migrated for work, her role in the new home was essentially work-related. According to informants, it was a loss to the community if women left or married foreigners.

Family and household were basic institutions on Zlarin and in Trenta. On Zlarin, after the nineteenth century, women took over caring for the household and worked in market-oriented vineyards. Women were almost exclusively responsible for the socialisation of children. Some men were absent for years or decades, and some never returned. "Father figures were distant", we were told. The Church primarily served a community of women and children. In the twentieth century, for example, the lack of men at folk festivals produced a myth that only women from Zlarin traditionally performed folk songs and dances (Sremac 2010).

Interestingly, both places worshiped women through religion. In Trenta, members of the religious community worship St. Ana (Jesus's Grandmother, 26 July) at the Church of Maria of Loretto (Marije Lavretanske, 1690) (Rutar 1989; Simonič 2014a). On Zlarin, the religious community still celebrates at the island's oldest church, Our Lady of Rašelj (Gospe od Rašelja, 1448), and regular masses are held at the Assumption of the Blessed Virgin Mary Church.

Village communities and cooperation in both sites used to be far more important to community members than they are today. Today, technology of the home and exchange has made households independent of one another. Mutual help is no longer necessary or obligatory for overcoming harsh living conditions, but informants expressed a conviction that mutual help still offers a chance to strengthen social ties. Favours in the sense of delayed positive reciprocity are quite common (taking care of each other's homes and rental properties, children or elders, repairing different kinds of equipment, bringing items and people to and from the mainland etc.). Negative reciprocity (market relations) touches visitors, tourists and other foreigners (comp. Sahlins 1972: 185-200; Simonič 2014a).

In terms of internal political differentiation, Trenta differs considerably from Zlarin due to at least three villages: Lepena, Soča and Trenta. In the past, the iron industry, and more recently the entrance point and cultural centre for Triglav National Park, have turned power relations in favour of Trenta village, but the village of Soča was larger and of more importance in the nineteenth century (the post office, church, school etc. were located there), which today causes some pushing and pulling in the management of the valley and tourism. On Zlarin, there used to be two villages. The seaside village of Zlarin was referred to as "a town" among former inhabitants of the island's primary village, Borovica, which was still without electricity or running water when the last inhabitants left in the 1980s. Surrounded by abandoned vineyards and olive groves, today the village is in ruins, and it serves only as hidden oasis for several new owners. Recent rivalries among settlements are unknown on Zlarin, which does not mean that island has not been without any internal 
political and economic contradictions (a long and strong tradition of autonomism in the nineteenth and twentieth centuries, known as autonomaši in Croatian, and communists vs. nationalists before and during World War II, Stulli: 1980: 28-33).

The disappearance of common land has been much more widespread on Zlarin then in Trenta. Agrarian communities (agrarne skupnosti) were formalised in the Habsburg Empire at the beginning of nineteenth century to continue the rights of (pre)feudal parishes (srenje; Repič 2014: 39). They have secured the right of exclusive usage for Alpine pastoralists inside the state's legal framework (feudal, later capitalist). People from Trenta have opposed the privatisation of forests and mountains many times, as they are essential for their livestock to graze freely and without disputes. In 1994, Slovenia again legally recognised the right of agrarian communities to use forests and high pastures, yet the Law on Forests from 1953 remains in force. The contemporary cooperative in Trenta generates a considerable amount of income and oversees the redistribution of resources among residents (timber, jobs, parking lots, trade etc.).

There is no record of common pool management of terrestrial resources on Zlarin (comp. Ostrom 1990), at least not in the nineteenth or twentieth centuries. Originally in the sixteenth century, large owners distributed minifundiums among colonists. It is unclear whether pastoralists originally practiced any kind of common property management for marginal, non-cultivated land, while there is topographical evidence that the peasant community was coordinated by assemblies (posobe; Kale 2009: 240).

In the same time as when the Alpine agrarian communities were reconfirmed by the state, Austrians also formalised fishing posts in Dalmatia (pošte). The intention was to rotate fishing rights fairly in various locations (by draw). From the end of the nineteenth century, the number of fishing cooperatives increased in Dalmatia, but the process reversed at the start of World War I. Still, on Zlarin, thirty nets and twenty fishing boats formed a fishing cooperative in 1922, and a new sponge cooperative was established in 1936 (Perić 1934, 1939). "After World War II, a socialist fishing cooperative was active for a few years", recalled an older man. Today, there are no cooperatives on Zlarin; common interests are orchestrated through political and administrative bodies, by the tourism association and by other civil societies.

A similar distinction is apparent in the ownership and management of essential equipment and means of production. In Trenta, before World War II, all members of the agrarian community shared mountain facilities for cheese making and followed a strict communitarian protocol. On Zlarin, the one and only olive press traditionally belonged to the Church, while wine presses were individual property.

The disintegration of old social models and the development of tourism industry in the second half of the twentieth century have minimalised traditional agricultural collective agreements in both places. Wealth or subsistence was not a result of careful planting, pasturing, fishing, harvesting and distribution of products, or of migration to other continents. It instead depended on the number and satisfaction of tourists and new property owners. 


\section{Tourism}

In the anthropology of tourism, two basic approaches have emerged: one focuses on guests and the political economy of modernity, and the other focuses on hosts and their responses to tourism. Thus, the impact of contact with vocational culture on tourists has been neglected, as were "local choices and constraints", "conditions under which people in the host destination become involved in tourism" (Stronza 2001: 266). Contemporary tourism both on Zlarin and in Trenta is a result of wider environmental and social backgrounds (constraints), than anthropological synchronicity, locality and interviews might reveal.

Tourism on the island and in the valley did not appear in the same time period, but it did in the same milieu: the Austrian legacy of leisure, health and imperial diversity. The Hapsburgs were an Alpine dynasty; therefore, tourism, which in the beginning was mainly aristocratic, was primarily oriented toward health resorts in the Alps. Trenta was an integral part of an increasing interest in mountains and national awareness in the Alpine area (e.g., F. Prešeren, Krst pri Savici, 1836; Šaver 2005). It was not until the beginning of the twentieth century that Dalmatia became a destination for southern spas and adventure (Baskar 2010). Bishops and some prominent laymen from Šibenik had mansions on Zlarin as early as the sixteenth century, mainly to be close to their properties, but also for leisure (Stulli 1980: 27; Lajić, Podgorelec and Babić 2001: 57; Muraj 1981: 277).

In a time of rapid population decline, tourism served as a lifeline for the remaining inhabitants. It was not welcomed immediately and by all, but it has slowly overtaken and redefined all other means of production, institutions and narratives. Interviews from both localities show a symptomatic difference between older and younger generations in respect to tourism. Tourism was not imposed, yet communities were attracted to it, largely after interventions in their subsistence (the Wine Clause, the Law on Forests, war, etc.). Instead of meat, cheese, oil, wine or timber, it now became possible to sell location, landscape, experience, and an image of Alpine or Mediterranean health, heritage, and also insularity. Signs of this consciousness appeared quite early in both places. In Trenta, it started with mountaineers at the end of nineteenth century (Abram 1907), and on Zlarin in 1922 with the Association for the Beautification and Commerce for Foreigners (Društvo za poljepšavanje i promet strancima). The very first promotional leaflet in Dalmatia was assumingly published for Zlarin in 1935 (s. n. 1935). ${ }^{6}$

Even though there have always been other modes of subsistence in play (e.g., regular employment outside the valley/island, pensions, fishing, forestry, gardening), tourism became most prominent in both places in the second half of the twentieth century. Today, tourism is a local monoculture in both localities, as much as agriculture had been earlier. It represents a kind of "culture core" (comp. Steward 1955), a preferable, dominant economic value of production and exchange. Considering

\footnotetext{
${ }^{6}$ Leaflet quotes no author, date, location or publishing house. After talking to the head of the local tourism office, I decided to use such a reference.
} 
the work load and gains of earlier or later subsistence, today it is rather unusual for residents to be engaged in agriculture rather than tourism (or other sorts of employment on the mainland).

Tourism enabled an individualised capitalisation of property on Zlarin and in Trenta (see Brezigar Miklavčič 1988) first by selling real estate, second by renting accommodations and third by selling other commodities (crafts, herb liquors, events - all forms of tangible and intangible heritage). Tourism stimulated a transformation of abandoned small estates (with savings and investment from abroad) into mansions, lodges and rental properties. It has also changed the ownership structure and the course of social stratification among residents due to their position in local tourism landscape, number of rental properties, returns, visitors, etc.

Contemporary tourism on Zlarin and in Trenta follow almost the same seasonal variations as agriculture used to, with less activity in winter and very intense amounts of work from Easter to October, with a peak in July and August. Seasonal variations in local tourism correspond with the biorhythm of European urban centres. The Soča River and Zlarin's sea are most pleasant during the summer months. The time from autumn to spring is reserved for local socializing, when volunteer firefighters' associations and folk dance troupes, churches, tourist associations and pubs play an integrative role in communities (see "tourism backstage" in Boissevain 1996). People involved in tourism think about common and individual strategies for the upcoming season and beyond.

Due to different ecological settings and history of colonisation/urbanisation, the tourist experience is also different: on Zlarin, most of the local population, visitors and activities are concentrated in the village of Zlarin and its marina, but in Trenta visitors move through the valley and its numerous paths, hills, springs and glades (comp. Ingold 2009). Zlarin's tourism is active mostly on beaches and the promenade, while in Trenta tourism is migratory and spreads throughout the valley with several gravitation points (like Soča spring). Tourism infrastructure and experience among hosts and guests depend on historical settlement patterns.

Like elsewhere in Europe, mass tourism reached Zlarin and Trenta in 1960s. The developing tourism industry and foreigners' seasonal immigration overlapped with locals' significant permanent emigration to industrial centres (from Trenta to Tolmin, Nova Gorica, Ljubljana etc.; from Zlarin to Šibenik, Split and Zagreb).

Some informants mentioned that historically the production of a tourist destination has been influenced by other neighbouring islands/valleys through either competition or cooperation. In the seventies, the "Trentars" (known in Slovenian as Trentarji) had to close down a hotel in Trenta village and sent the staff to Bovec, which then became the regional priority. Most of the opportunities for survival were outside the valley at that time. Today, most people in Trenta are aware of the valley's position in the tourism industry (Triglav National Park, the Alpine Convention, sports, schools, music etc.). In the 1970s, Zlarin was challenged by Vodice, a neighbouring and fast-growing costal tourist resort. Today, in the eyes of "Zlarinians" (known in Croatian as Zlarinjani) Vodice is associated with being wild, loud 
and crowded, and with a generally unpleasant kind of tourism. A decade ago, a new initiative called Bodulska pripetavanja (Islanders' Sport Games in the local dialect) connected people from the Šibenik archipelago through various sports competitions and entertainment.

New holiday homes and rental properties have been built or rearranged since the 1980s. In the Trenta Valley, newcomers' holiday facilities have slowly outnumbered those of permanent residents: "weekenders" now own more than sixty percent of all land (Vranješ 2006). Just like people in Trenta, those from Zlarin sold land and houses. In this case, however, more than half of all properties were recently sold to a single individual named Ante Maglica, an American industrialist and millionaire with family ties to the island and some childhood experience there. The economic crisis after the Croatian War of Independence (1991-1995) forced many people to quickly sell their family inheritance. Whether such an ownership structure is a sign of Mediterranean patronage (comp. Gilmore 1982: 180), or just a redistribution of (abandoned) resources and reinvestment into tourism (economic adjustment) remains an open question. Mr. Maglica is an important owner of properties scattered around the island, but as "local foreigner" he seems to hold no real political power. The opposite is the case in the Trenta Valley where two important remaining farmers from Trenta and Soča still wield a great deal of influence, although their properties are statistically marginal.

On Zlarin, the new owners are located mostly in or in the immediate outskirts of the settlement, while in Trenta their lodges are in different spots often hidden from the main roads. Neither on Zlarin nor in Trenta is there one dominant provider of accommodation. The numbers of suites and rooms at the TNP Info Centre in Trenta or at Hotel Koralj on Zlarin are currently marginal in respect to all available rooms, houses, or campsites.

These Alpine and Mediterranean examples are more prone to the ecological contents of tourism in comparison to the "mainland". King and Steward (1996, cit. in Stronza 2001: 276) noted that the "positive impacts of ecotourism are likely to be the greatest when the indigenous culture is already in a state of decline as a result of natural resources scarcity". Trenta has especially benefited from Triglav National Park, and local residents are fully aware of this. Due to heavy transit through the valley during the summer months (approx. 250,000 people per season visit or pass through daily), it is difficult to understand how Trenta was chosen to become part of nature park, while Zlarin has not yet been considered for one, even though there are almost no cars on the island and it only has one settlement.

Another significant distinction between both sites deals with the heritisation and commodification of World War I. During the war, Trenta was on the front line and was devastated. Also as a result of World War I, when Austria used Russian POWs to build a road over Vršič, the Trenta valley became accessible from both directions. Great social turmoil during the war introduced the valley as a spot for "dark tourism” (comp. Lisle 2007), which was significant at the war's recent centennial. Zlarin's geopolitical position was not a focus of bloodshed and human suffering, so there is 
nothing to capitalise on. There is nothing more than the Italian army barracks, which have been left in ruins.

Today, Trenta offers five campsites, three tourist farms, four taverns, two inns, two congress halls, fifteen apartment providers, thirteen room providers, and seven mountain cottages. Statistical records show 150,000 overnight stays per year. On Zlarin, the proportions are much smaller: barely more than 25,000 overnight stays were recorded in season 2015 (TZ Zlarin 2015), but statistics are never completely accurate. The only campsite on Zlarin is barely functional. Tourists at both sites come mostly from capital cities and other parts of the Alpe-Adria region.

Tangible and intangible cultural heritage has become a commodity (see RihtmanAuguštin 1970). There are no food surpluses to sell, but accommodation, dishes, crafts (coral, cheese, herb liquors and souvenirs) can be sold, and annual summer events (religious holidays and masses, or parties like Trentarski senjem, Zlarinska večer and Sardelijada) can be as well. It should be noted that the "human pool" is small: only a small group of around ten to fifteen people manage all public life on Zlarin and in Trenta. Both groups use different institutions and their networks (tourist associations, folklore societies, volunteer firefighters' associations, hunting associations, and other personal connections, etc.) to maintain the local community and culture.

The TNP Info Centre in the village of Trenta was an important state investment in the presentation of social memory and the social reorientation toward tourism. Perhaps similar effects will result from a recently approved project called the Hrvatski centar koralja (Croatian Coral Centre), which is a joint programme between local residents and the Croatian Ministry of Regional Development, and is meant to promote tourism on Zlarin and throughout the archipelago (Buneta 2015).

\section{Conclusion}

This paper combines two national streams of an ethnological description of "insulated communities". Slovenian ethnologists have been interested in the Alpine region as a special cultural area inside a national territory (e.g., Novak 1960; Cevc 1972). Ethnography was mostly a historical description of a local way of life and its "disintegration" in the twentieth century. Recent anthropological research has opened the cultural space of Alpine communities to the Alps in general, to empires, migrations, tourism, etc. (e.g., Vranješ 2006; Kozorog 2013; Baskar 2010). Croatian ethnological interest in the nation's islands clashed with their remarkable depopulation in the 1950s, when ethnography was also saving disappearing cultural traits and inheritance. The most recent contribution to island studies emphasizes a much broader, contextual approach: the relationship between islands and various dominant political and economic discourses (Prica and Jelavić 2009).

Gilmore (1982) and Viazzo (2014) offer an exposition of facts that is different from traditional ethnographic and heritage studies in the Alps and the Adriatic. 
Their methodology is a distinct suggestion of where to look for contextual or comparative data. I have taken one step further by applying their approach to a comparison between two selected localities, which, in terms of social and academic imaginations, belong to different environmental and cultural milieus: the Alpine and the Mediterranean.

The strongly defined geographical insularity of Zlarin Island and the Trenta Valley has certainly influenced the residents' possibilities and perception of their societies as carriers of encapsulated traditions. However, their origins and their political economies reveal that they were always relatively close to main cultural centres: as property, as a place for investment, a line of defence, nostalgia or as recreation. Both groups of colonists brought a cultural and economic model from their places of origin: they enforced and adjusted agriculture and pasturing to new soils for their survival, but at the same time they produced goods for imperial and state markets and administrations (wine, oil, timber, iron, cheese and a labour force). Insularity was therefore more a question of sharply defined territories, rather than an illustration of their cultural or economic conditions. Their histories are series of discontinuities: colonisation, political systems, direct state interventions, gender relations, properties, borders, migrations etc. The insularity of the island and the valley is a geographical statement, which can only determine the scope of different subsistence models like pasturing, agriculture, forestry and tourism. However, these models themselves have been structured in regards to property owners, and to state, religious and other distant authorities like the administrations in Vienna, Venice, Zagreb, Ljubljana etc. In other words, their subsistence and identity have always been relational. Frequent emigration and immigration are also significant factors in the open social and cultural history of both places.

According to this perspective, the environment works as a limiting factor for subsistence. Their limited possibility to increase the population and agricultural production made them inappropriate for later industrial development and urbanisation. However, they were still subjected to twentieth century modernisation in the sense of permanent infrastructural advancement, administration and positioning in regional and global society. In their new development strategy, an assumption of underdevelopment (absence of industry) became an opportunity because it offered an escape for city dwellers and considerable earnings for property owners. The ownership structure in both places changed completely and decisively in the last century for the sake of tourism. Tourism has also increased the value of real estate and overall life expenses for local residents. Interviews are filled with data pointing to such historical reasoning of local tourism and their new "culture core" (comp. Steward 1955).

Today, tourism supports fewer people then agriculture did in the nineteenth century. Tourism is less labour intensive or demanding, and is more economically rewarding for the majority. It also appears to be more sustainable in comparison to previous agricultural models because local forests are recovering (pastures and vineyards have been abandoned, the microclimate is cooling). The number of inhab- 
itants is much smaller in comparison to those in the nineteenth century, so social pressure on the environment should be weaker, but this is only true in the winter. Summer visitors need a great deal of additional resources (food, electricity, water), with all accompanying technologies and services - and also produce more waste.

Even though (eco)tourism is now a generally accepted development strategy in both places, management of these destinations on the local level (tactical or strategic coordination, branding, events etc.) depends on a very small remaining group of younger inhabitants. The majority of the population is over sixty years old. These active groups use selected parts of tangible and intangible inheritance/heritage like food, clothing, housing, religious and other social events, hiking trails, hunting and fishing, crafts and arts, etc. as a source for the advancement of tourism and society.

\section{REFERENCES}

Abram, Jože (Abram., Jos.). 1907. “Opis Trente”. Planinski vestnik 13.

Abram, Jože (Abram., Jos.). 1907a. “Opis Trente. I. Lega”. Planinski vestnik 13/4: 52-56.

Abram, Jože (Abram., Jos.). 1907b. “Opis Trente. I. Lega (Dalje)”. Planinski vestnik 13/5: 65-70.

Abram, Jože (Abram., Jos.). 1907c. “Opis Trente. I. Lega (Dalje)”. Planinski vestnik 13/6: 81-86.

Abram, Jože (Abram., Jos.). 1907d. “Opis Trente. II. Zgodovina”. Planinski vestnik 13/7: 101-103.

Abram, Jože (Abram., Jos.). 1907e. “Opis Trente. II. Zgodovina (Dalje)”. Planinski vestnik 13/8: 117-119.

Abram, Jože (Abram., Jos.). 1907f. “Opis Trente. III. Ljudstvo”. Planinski vestnik 13/9: 133-135.

Abram, Jože (Abram., Jos.). 1907g. “Opis Trente. III. Ljudstvo (Dalje)”. Planinski vestnik 13/10: 149-153.

Abram, Jože (Abram., Jos.). 1907h. “Opis Trente. III. Ljudstvo (Dalje)”. Planinski vestnik 13/11: 165-168.

Abram, Jože (Abram., Jos.). 1907i. “Opis Trente. III. Ljudstvo (Konec)”. Planinski vestnik 13/12: 181-185.

Appadurai, Arjun. 2003. Modernity at Large. Cultural Dimensions of Globalisation. Minneapolis, London: University of Minnesota Press.

Babić, Dragutin, Ivan Lajić and Sonja Podgorelec. 2004. Otoci dviju generacija. Zagreb: Institut za migracije i narodnosti.

Baskar, Bojan. 2010. "Southbound, to the Austrian Riviera. The Habsburg Patronage of Tourism in the Eastern Adriatic”. Anthropological Notebooks 16/1: 9-22.

Bezić, Jerko. 1981. "Folklorna glazba otoka Zlarina”. Narodna umjetnost 18: 27-148.

Bezić, Jerko et al. 1982. Povijesti i tradicije otoka Zlarina. Zagreb: Zavod za istraživanje folklora Instituta za filologiju i folkloristiku.

Blažević, Milivoj. 2007. “Prilog povijesti poljoprivrede šibenskog područja od 1921. do 1941.”. Radovi Zavoda povijesnih znanosti, HAZU 49: 645-689.

Boissevain, Jeremy. 1996. "Introduction". In Coping with Tourists. European Reactions to Mass Tourism. Jeremy Boissevain, ed. Providence, Oxford: Berghahn Books, 1-26.

Brezigar Miklavčič, Inga. 1988. "Prispevek k etnološki podobi Bovškega”. In Pokrajina in ljudje na Bovškem (Alpski mladinski raziskovalni tabori, Bovec, 1985-1987). Jurij Kunaver, ed. Ljubljana: Republiški koordinacijski odbor Gibanja Znanost mladini, 81-108.

Buneta, Katarina. 2015. Uloga Hrvatskog centra koralja u revitalizaciji kulturnog identiteta otoka Zlarina. Unpublished BA Thesis. Šibenik: Veleučilište u Šibeniku.

Carneiro, Robert L. 1970. “A Theory of the Origin of the State”. Science, New Series 169/3947: 733-738.

Cevc, Tone. 1972. Velika planina: življenje, delo in izročilo pastirjev. Ljubljana: Državna založba Slovenije.

Cohen, Anthony P. 1985. Symbolic Construction of Community. London: Routledge. [https://doi. org/10.4324/9780203323373]

Cole, John W. 1972. “Cultural Adaptation in the Eastern Alps”. Anthropological Quarterly (Special Issue Dynamics of Ownership in the Circum-Alpine Area) 45/3: 158-176.

Čepič, Zdenko. 1995. Agrarna reforma in kolonizacija v Sloveniji. Maribor: Založba obzorja.

Davis, John. 1977. People of the Mediterranean. An Essay in Comparative Social Anthropology. London, Henley, Boston: Routledge \& Kegan Paul.

Dean, Dušan. 2004. O ljudima moga otoka. Zagreb: Institut za migracije i narodnosti.

Defilippis, Josip. 2013. “Hrvatsko mediteransko selo kroz stoljeća”. Sociologija i prostor 51/2: 291-302. 
Dolenc, Janez. 1988. “Prispevek za zgodovino Bovškega pod Italijo 1918-1941”. In Pokrajina in ljudje na Bovškem (Alpski mladinski raziskovalni tabori, Bovec, 1985-1987). Jurij Kunaver, ed. Ljubljana: Republiški koordinacijski odbor Gibanja Znanost mladini, 29-36.

Douglas, Mary. 1986. How Institutions Think. New York: Syracuse University Press.

Edinost. 1892. "Vinska klavzula v avstrijsko-laški trgovinski pogodbi”. Edinost, 11 June, 17/47: 1, 3.

Fikfak, Jurij, Tatiana Bajuk Senčar and Dan Podjed, eds. 2014. Triglavski narodni park: akterji, dediščne. Ljubljana: Založba ZRC (Collegium Graphicum).

Fortes, Meyer and E. E. Evans-Pritchard, eds. 1950. African Political Systems. London, New York, Toronto: International African Institute, Oxford University Press.

Fortis, Abbe Alberto. 1778. Travels into Dalmatia. London: J. Robson.

Gilmore, David D. 1982. "Anthropology of the Mediterranean Area”. Annual Review of Anthropology 11: 175-205. [https://doi.org/10.1146/annurev.an.11.100182.001135]

Ingold, Tim. 2009. “Against Space. Place, Movement, Knowledge”. In Boundless Worlds. An Anthropological Approach to Movement. Peter W. Kirby, ed. New York: Berghahn Books, 29-44.

Kale, Jadran. 2009. "Posthumni život otočnog pašnjaka”. In Destinacije čežnje, lokacije samoće. Uvidi u kulturu i razvojne mogućnosti hrvatskih otoka. Ines Prica and Željka Jelavić, eds. Zagreb: Institut za etnologiju i folkloristiku, Hrvatsko etnološko društvo, 235-268.

Komac, Vlasta Terezija. 2003. Zakladnica bovške preteklosti. Idrija: Založba Bogataj.

Korenčić, Mirko. 1979. Naselja i stanovništvo SR Hrvatske 1857-1971. Zagreb: Jugoslavenska akademija znanosti i umjetnosti.

Kozorog, Miha. 2013. Festivalski kraji. Koncepti, politike in upanje na periferiji. Ljubljana: Znanstvena založba Filozofske fakultete.

Kunaver, Jurij. 1988. “Alpski mladinski raziskovalni tabori v Bovcu 1985-1987”. In Pokrajina in ljudje na Bovškem (Alpski mladinski raziskovalni tabori, Bovec, 1985-1987). Jurij Kunaver, ed. Ljubljana: Republiški koordinacijski odbor Gibanja Znanost mladini, 5-8.

Lajić, Ivan, Sonja Podgorelec and Dragutin Babić. 2001. Otoci. Ostati ili otići? Zagreb: Institut za migracije i narodnosti.

Leach, Edmund. 1970. Political Systems of Highland Burma. A Study of Kachin Social Structure. London: The Athlone Press.

Lendvai, Paul. 2003. The Hungarians. A Thousand Years of Victory in Defeat. Princeton, New Jersey: Princeton University Press. [https://doi.org/10.1515/9781400851522]

Lisle, Debbie. 2007. "Defending Voyeurism. Dark Tourism and the Problem of Global Security”. In Tourism and Politics. Global Frameworks and Local Realities. Peter M. Burns and Marina Novelli, eds. Amsterdam: Elsevier, 333-346. [https://doi.org/10.1016/B978-0-08-045075-9.50022-4]

Lopašić, Alexander. 2001. “Mediterranean Islands. A Concept”. Collegium Anthropologicum 25/1: 363-370.

Lowenthal, David. 1998. The Heritage Crusade and the Spoils of History. Cambridge: Cambridge University Press. [https://doi.org/10.1017/CBO9780511523809]

Malinowski, Bronislaw. 1984. Argonauts of the Western Pacific. Long Grove: Waveland Press.

Marks, Liljana. 1980. "Usmene pripovijetke i predaje s otoka Zlarina”. Narodna umjetnost 17: 217-280.

Mlekuž, Iztok. 2002. "Gozd v kulturni krajini na Bovškem”. In Soški razgovori I. Zbornik za domoznanstvo. Jurij Kunaver, ed. Bovec: Zgodovinska sekcija Kulturnega društva Golobar, 205-214.

Moran, Emilio. 2000. Human Adaptability. An Introduction to Ecological Anthropology. Colorado: Westview Press.

Muraj, Aleksandra. 1981. “Obrisi svakodnevnog života zlarinskih težaka”. Narodna umjetnost 18: 257-318.

Narodna umjetnost 17. 1980.

Narodna umjetnost 18. 1981.

Netting, Robert McC. 2007. "Links and Boundaries. Reconsidering the Alpine Village as Ecosystem”. In Environmental Anthropology. A Historical Reader. Michael R. Dove and Caron Carpenter, eds. Malden, Oxford, Carlton: Blackwell Publishing, 309-318.

Noé, Heinrich. 1870. Dalmatien und Seine Inselwelt. Wien: A. Hartleben's Verlag.

Novak, Vilko. 1960. Slovenska ljudska kultura. Ljubljana: Državna založba Slovenije.

Ostrom, Elinor. 1990. Governing the Commons. Cambridge et al.: Cambridge University Press. [https://doi. org/10.1017/CBO9780511807763]

Panjek, Aleksander. 2002. “O gospodarskem pomenu meje”. In Soški razgovori I. Zbornik za domoznanstvo. Jurij Kunaver, ed. Bovec: Zgodovinska sekcija Kulturnega društva Golobar, 215-226.

Perić, Jelka. 1934. “Ribarstvo u Dalmaciji”. Zbornik za narodni život i običaje 29/2: 119-147.

Perić, Jelka. 1939. “Lov koralja i spužava u Dalmaciji”. Zbornik za narodni život i običaje 32/1: 157-186.

Peričić, Šime. 1980. Dalmacija uoči pada Mletačke republike. Zagreb: Sveučilište u Zagrebu, Institut za hrvatsku povijest.

Prica, Ines and Željka Jelavić, eds. 2009. Destinacije čežnje, lokacije samoće. Uvidi u kulturu i razvojne mogućnosti hrvatskih otoka. Zagreb: Institut za etnologiju i folkloristiku, Hrvatsko etnološko društvo. 
Rajković, Zorica. 1981. “Običaji otoka Zlarina”. Narodna umjetnost 18: 221-255.

Repič, Jaka. 2014. "Gibanje kot prostorske prakse in ekonomske strategije na primeru družinskega sirarstva v Bohinju”. Ars \& Humanitas (Solidarnost in vzajemnost v času recesije. Razumevanje starih in novih vrednosti in vrednot v poznem kapitalizmu) 8/1:38-57.

Rihtman-Auguštin, Dunja. 1970. “Tradicionalna kultura i turizam. Dvije neiskorištene šanse”. Dometi 3/6: 4-11.

Rutar, Simon. 1889. “Das Annenfest in der Trenta”. Leibacher Zeitung 180/185: 1577-1580.

[s. n.] 1935. Zlarin kod Šibenika. S. 1 .

Sahlins, Marshall. 1972. Stone Age Economics. New York.

Shell, Marc. 2014. Islandology. Geography, Rhetoric, Politics. Stanford: Stanford University Press.

Simonič, Peter. 2014a. "Pretekle in sodobne oblike skupnega v dolini Trente”. Ars \& Humanitas (Solidarnost in vzajemnost v času recesije. Razumevanje starih in novih vrednosti in vrednot v poznem kapitalizmu) 8/1:15-37.

Simonič, Peter, ed. 2014b. Gradivo Triglavski narodni park 2011-2014. Ljubljana: Filozofska fakulteta, Oddelek za etnologijo in kulturno antropologijo (unpublished).

Simonič, Peter, ed. 2017. Zlarin - Etnografsko gradivo - intervjuji, eseji, registri. Ljubljana: Univerza v Ljubljani, Filozofska fakulteta, Oddelek za etnologijo in kuturno antropologijo (unpublished).

Sremac, Stjepan. 2010. Povijest i praksa scenske primjene folklornog plesa u Hrvata. Izmedu društvene i kulturne potrebe, politike, kulturnog i nacionalnog identiteta. Zagreb: Institut za etnologiju i folkloristiku.

Steward, Julian. 1955. Theory of Culture Change. The Methodology of Multilinear Evolution. Urbana: University of Illinois.

Strathern, Paul. 2013. The Venetians. New York, London: Pegasus Books.

Stronza, Amanda. 2001. "Anthropology of Tourism. Forging New Ground for Ecotourism and Other Alternatives". Annual Review of Anthropology 30: 261-283. [https://doi.org/10.1146/annurev.anthro.30.1.261]

Stulli, Bernard. 1980. "Povijest Zlarina”. Narodna umjetnost 17: 11-60.

Šaver, Boštjan. 2005. Nazaj v planinski raj. Alpska kultura slovenstva in mitologija Triglava. Ljubljana: Fakulteta za družbene vede.

TZ Zlarin. 2015. Izvještaj o radu Turističke zajednice mjesta Zlarin za razdoblje 1.1. - 31.12. 2015. http://www.tzzlarin.hr/wp-content/uploads/2016/02/Izvještaj-o-radu-2015.pdf (accessed 28. 5. 2017).

Viazzo, Pier Paolo. 2014. Alpske skupnosti. Okolje, prebivalstvo in družbena struktura. Ljubljana: Studia Humanitatis. Vilfan, Sergij. 1996. Zgodovinska pravotvornost in Slovenci. Ljubljana: Cankarjeva založba.

Vranješ, Matej. 2006. Prostor, teritorij, kraj. Produkcije lokalnosti v Trenti in na Soči. Koper: Univerza na Primorskem.

Wallerstein, Immanuel. 1998. “The Time of Space and the Space of Time. The Future of Social Sciences”. Political Geography 17/1: 71-82. [https://doi.org/10.1016/S0962-6298(96)00097-2]

Wolf, Eric. 1973. Peasant Wars in the Twentieth Century. London: Faber \& Faber Limited.

Wolf, Eric R. 1998-1999. Evropa in ljudstva brez zgodovine. Ljubljana: Studia Humanitatis.

Wolff, Larry. 1997. "Venice and the Slavs of Dalmatia. The Drama of the Adriatic Empire in the Venetian Enlightment”. Slavic Review 56/3: 428-455. [https://doi.org/10.2307/2500924]

Wraber, Tone. 1980. Trenta. Maribor: Obzorja.

\section{Inzularnost i politička ekonomija turizma. Antropološka analiza Zlarina i Trente}

Rad povezuje okolišne, komunitarne i političko-ekonomske silnice kako bi objasnio kulturnu baštinu i turizam na otoku Zlarinu (Hrvatska, Dalmacija) i u dolini Trenta (Slovenija, Alpe). Ta dva odabrana mjesta pripadaju različitim zemljopisno-kulturnim područjima i akademskim tradicijama, ali također dijele brojne zajedničke osobine, kao što su kasna kolonizacija, intenzivna poljoprivreda i prenaseljenost, pad broja stanovnika u 20. stoljeću, promjena vlasničke strukture, rani začeci turizma i korištenje inzularnosti kao prednosti u turističkoj strategiji. Komparativna analiza pruža mogućnost ponovnog promišljanja etnološkog pristupa zajednicama i kulturama kao inzularnim entitetima.

Ključne riječi: Jadran, Alpe, poljoprivreda, okoliš, demografija, industrijalizacija, stres, kulturna baština, Zlarin, Trenta 